\title{
Restriction fragment length polymorphisms associated with the factor VIII and factor IX genes in Polynesians
}

\author{
Neil S Van-de-Water, Derry Ridgway, Paul A Ockelford
}

\begin{abstract}
New Zealand Maoris (72 X chromosomes) have been compared with Pacific Island Polynesians (121 $X$ chromosomes) and Caucasian New Zealanders (51 X chromosomes) as a control group to determine the allelic frequency of six RFLPs associated with the genes for two $X$ linked diseases (haemophilia $A$ and haemophilia B). RFLPs examined were $B c I, X b a I$, and $B g I$ within the factor VIII gene, the factor VIII extragenic TaqI system, and the factor $\mathrm{X}$ intragenic TaqI and $X \mathrm{mnI}$ sites. The information obtained facilitates the design of strategies for both carrier detection and prenatal diagnosis of haemophilia A within these groups. Strong linkage disequilibrium was observed between the factor VIII Bcll and XbaI sites in Polynesians. Genetic counselling for Polynesians with haemophilia B continues, however, to rely on phenotypic diagnosis. The RFLP data from the two separate loci on the $\mathbf{X}$ chromosome in Polynesians show similarities with Chinese and Japanese populations, reinforcing theories of an early Polynesian ancestry originating in east Asia.
\end{abstract}

The incidence of haemophilia $A$ averages 1 to 2 per 10000 males throughout the world and haemophilia $B$ has an incidence of one fifth that of haemophilia A. The incidence in New Zealand is similar. ${ }^{1}$ Accurate carrier diagnosis and early prenatal detection, both important components of comprehensive haemophilia care, have been greatly improved by the development

Department of Haematology, Auckland Hospital, Auckland, New Zealand.

N S Van-de-Water, D Ridgway, ${ }^{*}$ P A Ockelford

Section of Haematology, Department of Molecular Medicine, School of Medicine, University of Auckland, Auckland, New Zealand.

N S Van-de-Water, D Ridgway, P A Ockelford

${ }^{*}$ Present address: Oregon Health Sciences University, Portland, USA.

Correspondence to Dr Van-de-Water.

Received for publication 22 May 1990.

Revised version accepted for publication 12 September 1990. of DNA genotyping. Restriction fragment length polymorphisms (RFLPs) can be used as linkage markers to determine the inheritance of normal or mutant haemophilia genes. When these RFLP markers are intragenic and informative in a kindred of interest, carrier status can be assigned with a theoretical accuracy exceeding $99 \% .^{2}$ A further benefit of using this technique is the early prenatal diagnosis (at 8 to 10 weeks) of abnormal males by chorionic villus sampling. Recent developments using the polymerase chain reaction (PCR) have been applied to RFLP analysis in haemophilia. ${ }^{3}$ These techniques have both shortened the time required to obtain a result and allowed small quantities of DNA to be analysed, an important factor when using DNA from chorionic villi for prenatal diagnosis. RFLP analysis is limited, however, by the number of polymorphic markers identified which are sufficiently common to be of use in general populations. This restricts the number of potentially informative cases.

The allelic frequency of any polymorphism within a population determines the usefulness of that RFLP for genetic counselling. For two allele systems, the most informative allelic frequency is $50 \%$, which results in a $50 \%$ rate of heterozygosity (and hence informativeness). The combination of two or more independent RFLPs will increase the rate of informativeness proportionately. In reality this is often complicated by linkage disequilibrium between polymorphic sites within the same gene. Among Caucasians the most useful RFLPs within the factor VIII gene are the $X b a I$ site in intron 22 , the $B c I I$ site in intron 18, and the BglI site in intron 25. Previous studies in Caucasian populations suggest that the use of this combination of RFLPs will result in $70 \%$ of women being informative. ${ }^{45}$ An additional 20 to $25 \%$ of women in these populations are informative when the closely linked extragenic $\operatorname{TaqI}$ site, with its $5 \%$ rate of error, is analysed. ${ }^{56}$ Several useful intragenic factor IX RFLPs have been reported. ${ }^{2}$ 7-10 Three frequently used factor IX RFLPs, a TaqI site in intron IV, an XmnI site in intron III, and a DdeI site in intron $I$ are reported to be informative in approximately $70 \%$ of Caucasian women when used in combination. ${ }^{2}$

Before DNA based genetic counselling can be implemented it is essential to establish the allelic 
frequencies of commonly used RFLPs in the local population. This is particularly important in populations of non-Caucasian origin because RFLPs may differ significantly among different ethnic groups. ${ }^{11-15}$ The Polynesian race is a distinct ethnic group and although New Zealand's population is predominantly Caucasian there is a significant Polynesian or partPolynesian community. At least $10 \%$ of the total New Zealand population, and approximately $10 \%$ of the haemophilia population, is Polynesian. We report here the results of a survey of six haemophilia related RFLP/probe systems in a sample of New Zealand resident Polynesians representing five different Pacific Island groups.

\section{Materials and methods \\ SUBJECTS}

Peripheral blood was drawn from 125 unrelated volunteer subjects after written informed consent was obtained in accordance with the requirements of the Auckland Hospital Research Ethics Committee. All subjects were residents of New Zealand and stated their race on the consent form. Subjects were included in the study if they were of $100 \%$ European heritage (Caucasians without Maori or Polynesian ancestors), were of $100 \%$ Pacific Island Polynesian heritage, or declared themselves to be Maori and to have $\geqslant 50 \%$ Maori heritage. Twenty-seven subjects (three males) were Caucasian, 37 subjects (two males) were New Zealand Maori, and 61 subjects (one male) were Pacific Island Polynesian. Among the non-Maori Polynesians, ten were Niue Islanders, 19 were Cook Islanders, four were Tongan, and 28 were Samoan.

\section{METHODS}

Blood was drawn directly into tubes containing CPD anticoagulant, and total genomic DNA was extracted by the method of Kunkel et al. ${ }^{16}$ DNA $(2.5$ to $5 \mu \mathrm{g})$ was digested with restriction endonucleases according to the manufacturers' recommendations. Restriction fragments were separated on 0.8 to $1.0 \%$ agarose gels and blotted onto Gene Screen Plus membranes (DuPont) by Southern transfer. ${ }^{17}$ Membranes were hybridised for approximately 24 hours at $42^{\circ} \mathrm{C}$ in formamide $(50 \%), 4 \times$ SSC, SDS $(1 \%)$, and $0.5 \%$ non-fat milk powder with DNA probe labelled with $\left[{ }^{32} \mathrm{P}\right] \mathrm{dCTP}$ by the random primer labelling system. ${ }^{18}$ After hybridisation, membranes were washed for five minutes in $2 \times \mathrm{SSC}$ at room temperature, then for 30 minutes in $2 \times S S C$ with SDS $(1 \%)$ at $65^{\circ} \mathrm{C}$, and then for 10 minutes in $0.1 \times S S C$ with SDS $(0.1 \%)$ at $65^{\circ} \mathrm{C}$. The membranes were left wet and exposed to $x$ ray film (X-Omat AR, Kodak) with intensifying screens at $-70^{\circ} \mathrm{C}$ for one to four days. The DNA probes used for the factor VIII gene included: (1) p114.12, supplied by the American Type Culture Collection (ATCC), which detects a Bcll polymorphism in intron $18^{19}$; (2) p482.6, supplied by ATCC, which detects an $X b a \mathrm{I}$ polymorphism in intron $22^{20}$; (3) cDNA-C, kindly supplied by the Genetics Institute (Cambridge, MA), which detects a $B g l I$ polymorphism in intron $25^{11}$; and (4) St14.1, kindly supplied by $\mathrm{Dr}$ J-L Mandel of Strasbourg, which detects a multiallelic TaqI RFLP system in an extragenic site. ${ }^{21}$ The DNA probe used for both the TaqI and XmnI RFLPs within the factor IX gene was probe VIII, kindly supplied by Professor G Brownlee of Oxford. ${ }^{2}$

\section{Results}

FACTOR VIII REGION

Allele frequencies, intragenic RFLPs

Table 1 shows the allelic frequencies for the three factor VIII intragenic RFLPs for each racial group. The frequencies for all three RFLPs were similar (within 95\% confidence interval) for Caucasian residents of New Zealand and other reported Caucasian populations, 561920 although the New Zealand frequency for the $B c l I$ polymorphism was relatively high (83\%). Polynesian allelic frequencies at the $B c l I$

Table 1 Allelic frequencies for restriction sites in the factor VIII gene.

\begin{tabular}{|c|c|c|c|c|c|c|}
\hline & \multicolumn{2}{|c|}{$B c l I$} & \multicolumn{2}{|c|}{$X b a I$} & \multicolumn{2}{|c|}{$B g l I$} \\
\hline & $\begin{array}{c}\text { No } \\
\text { positive }\end{array}$ & $\begin{array}{c}\% \\
\text { positive }\end{array}$ & $\begin{array}{c}\text { No } \\
\text { positive }\end{array}$ & $\begin{array}{c}\% \\
\text { positive }\end{array}$ & $\begin{array}{c}\text { No } \\
\text { positive }\end{array}$ & $\begin{array}{c}\% \\
\text { positive }\end{array}$ \\
\hline $\begin{array}{l}\text { Caucasians (NZ) } \\
\text { Caucasians (other)t } \\
\text { Maori (NZ) } \\
\text { Pacific Island }\end{array}$ & $\begin{array}{c}39 / 47 \\
294 / 425 \\
46 / 72\end{array}$ & $\begin{array}{l}83(69-90)^{*} \\
69 \\
66(52-76)\end{array}$ & $\begin{array}{c}26 / 47 \\
105 / 187 \\
41 / 72\end{array}$ & $\begin{array}{l}55(40-70) \\
56 \\
57(45-69)\end{array}$ & $\begin{array}{c}42 / 51 \\
118 / 139 \\
68 / 72\end{array}$ & $\begin{array}{l}82(69-91) \\
85 \\
94(87-98)\end{array}$ \\
\hline $\begin{array}{l}\text { Polynesian totals } \\
\text { Cook Islanders } \\
\text { Tongans } \\
\text { Samoans } \\
\text { Niueans } \\
\text { Chinesef }\end{array}$ & $\begin{array}{c}67 / 121 \\
19 / 38 \\
5 / 8 \\
37 / 56 \\
6 / 19 \\
79 / 96\end{array}$ & $55(46-64)$ & $\begin{array}{c}58 / 115 \\
15 / 34 \\
4 / 8 \\
35 / 56 \\
4 / 17 \\
28 / 49\end{array}$ & $50(41-60)$ & $\begin{array}{c}119 / 120 \\
37 / 38 \\
8 / 8 \\
56 / 56 \\
18 / 18 \\
54 / 54\end{array}$ & $99(95-99)$ \\
\hline
\end{tabular}

*\% positive ( $95 \%$ confidence interval).

tFrom Antonarakis et al, ${ }^{11}$ Gitschier et al, ${ }^{19}$ Moodie et al, ${ }^{5}$ and Wion et al. ${ }^{20}$ $\ddagger$ From Chan et al. ${ }^{15}$ 
intron 18 site were slightly lower than those reported for both Caucasian and Chinese populations. ${ }^{5} 1520$ The frequency of the $X b a I / i n t r o n ~ 22$ site in the Polynesian group was similar to Caucasian and Chinese values, but there was a virtual absence of polymorphism at the $B g l l /$ intron 25 site. New Zealand Maoris had allelic frequencies intermediate between Caucasians and Polynesians at the $B g l I$ site.

For each RFLP, the expected and observed percentage of informative women, as determined by the Hardy-Weinberg principle, was similar. For the Bcll/intron 18 RFLP, $28 \%$ of Caucasians $(n=22)$, $46 \%$ of Maoris $(n=35)$, and $49 \%$ of Pacific Island Polynesians $(n=66)$ were informative. For the $\mathrm{XbaI} /$ intron 22 RFLP, $50 \%$ of Caucasians $(n=22), 48 \%$ of Maoris $(n=35)$, and $50 \%$ of Pacific Island Polynesians $(n=66)$ were informative. For the $B g l I /$ intron 25 RFLP, the values were $19 \%$ of Caucasians $(n=24)$, $10 \%$ of Maoris $(n=35)$, and $1 \%$ of Pacific Island Polynesians $(n=69)$.

For comparative purposes, previously reported values in a Chinese population ${ }^{15}$ for these three intragenic RFLPs are also included in table 1.

\section{Linkage disequilibrium, intragenic RFLPs}

Linkage disequilibrium between the $B c l$ /intron 18 and the $\mathrm{XbaI} /$ intron $22 \mathrm{RFLP}$ sites was not detected in the control population of 20 Caucasian females. Examination of the $B g l l /$ intron 25 site did not improve on the $60 \%$ informativeness of the first two RFLPs in this group (figure). In contrast, among 35 Maori females and 57 Pacific Island Polynesian females, for whom all three intragenic RFLPs were studied, the increase in informativeness obtained by two or three RFLPs in the same female was less than expected, owing to strong linkage disequilibrium between the $B c l I$ and $X b a I$ sites in introns 18 and 22 . Precise figures for the association of the alleles at the $B c I I$ and $X b a I$ sites could not be determined in this study since the majority of the subjects were female, and for those who were doubly heterozygous the phase of the alleles remained in doubt.

The estimated frequency for each allelic pair was based on male subjects and non-doubly heterozygous females. A strong association between $B c l I$ fragment 0.9 and $X b a I$ fragment 1.4 and a corresponding strong association between $B c l I$ fragment 1.2 and $\mathrm{XbaI}$ fragment 6.2 was observed among both groups of Polynesian subjects.

\section{Allele frequencies, extragenic RFLPs}

At the factor VIII linked extragenic TaqI site, striking differences in allelic frequencies were observed between Polynesian and Caucasian subjects. As shown in table 2 , the frequencies of system 1 alleles 5-6 and 8 were higher among both groups of Polynesians, and the frequencies of alleles 3 and 4 were lower. Within system 2 , the $\beta$ fragment, which was not found in Caucasians, occurred in $41 \%$ of Pacific Island Polynesians and $11 \%$ of Maoris. The combined informativeness of the system 1 and system 2 TaqI RFLPs was between $60 \%$ and $70 \%$ for each ethnic group. The improvement in informativeness of RFLP analysis provided by the addition of the extragenic TaqI study to the three intragenic studies was examined in each population. Among six Caucasian females, uninformative after full intragenic study, three $(50 \%)$ were informative by $\mathrm{TaqI}$ analysis. Among 12 Maori females uninformative after full intragenic study, seven ( $58 \%$ ) were informative after

Table 2 Frequencies of the allelic TaqI fragments and informativeness shown by the St14.1 probe.

\begin{tabular}{clll}
\hline & $\begin{array}{c}\text { New Zealand } \\
\text { Caucasians (\%) }\end{array}$ & $\begin{array}{c}\text { New Zealand } \\
\text { Maoris (\%) }\end{array}$ & $\begin{array}{c}\text { Pacific Is } \\
\text { Polynesians (\%) }\end{array}$ \\
\hline System 1 & $(\mathrm{n}=32)^{*}$ & $(\mathrm{n}=43)$ & $(\mathrm{n}=100)$ \\
Allele 1 & 0 & 0 & 0 \\
2 & 6 & 7 & 6 \\
3 & 41 & 7 & 6 \\
4 & 25 & 2 & 4 \\
$5-6$ & 16 & 38 & 53 \\
7 & 3 & 11 & 7 \\
8 & 9 & 35 & 24 \\
System 2 & $(\mathrm{n}=32)$ & $(\mathrm{n}=44)$ & $(\mathrm{n}=110)$ \\
$\alpha$ & 100 & 89 & 59 \\
$\beta$ & 0 & 11 & 41 \\
Informativeness & & & \\
Sys 1 & $(16$ females) & $(21$ females) & $(49$ females) \\
Sys 2 & 69 & 62 & 45 \\
Combined & 69 & 67 & 41 \\
\end{tabular}

${ }^{*} \mathrm{n}=$ number of $\mathrm{X}$ chromosomes analysed. 
Table 3 Allelic frequencies for restriction sites in the factor IX gene.

\begin{tabular}{|c|c|c|c|c|}
\hline & \multicolumn{2}{|c|}{ TaqI } & \multicolumn{2}{|c|}{$X m n I$} \\
\hline & No positive & $\%$ positive & No positive & $\%$ positive \\
\hline $\begin{array}{l}\text { Caucasians (NZ) } \\
\text { Caucasians (other)† } \\
\text { Maori (NZ) } \\
\text { Pacific Island }\end{array}$ & $\begin{array}{l}17 / 51 \\
61 / 192 \\
5 / 72\end{array}$ & $\begin{array}{l}33(19-47)^{*} \\
32 \\
7(3-16)\end{array}$ & $\begin{array}{r}11 / 51 \\
21 / 72 \\
4 / 72\end{array}$ & $\begin{array}{c}22(12-36) \\
29 \\
6(2-15)\end{array}$ \\
\hline $\begin{array}{l}\text { Polynesian totals } \\
\text { Cook Islanders } \\
\text { Tongans } \\
\text { Samoans } \\
\text { Niueans } \\
\text { Chinese } f \\
\text { Japanese } \int\end{array}$ & $\begin{array}{l}1 / 120 \\
0 / 38 \\
0 / 8 \\
1 / 56 \\
0 / 18 \\
2 / 68 \\
0 / 81\end{array}$ & $0.8(0.1-5)$ & $\begin{array}{l}0 / 116 \\
0 / 36 \\
0 / 8 \\
0 / 56 \\
0 / 16 \\
2 / 56 \\
0 / 81\end{array}$ & $0(0-4)$ \\
\hline
\end{tabular}

*\% positive ( $95 \%$ confidence interval).

†From Winship et al, ${ }^{2}$ Camarino et al, ${ }^{9}$ and Hassan et al. ${ }^{22}$

†From Lubahn et al. ${ }^{13}$

fFrom Kojima et al. ${ }^{12}$

TaqI analysis. Among 28 Pacific Island Polynesian females uninformative after full intragenic study, 16 (57\%) were informative after TaqI analysis. Informativeness for the factor VIII gene based on examination of all four RFLPs was, respectively, $77 \%, 76 \%$, and $78 \%$ for the three ethnic groups.

\section{FACTOR IX REGION}

Table 3 shows the allelic frequencies for the TaqI RFLP in intron IV and the XmnI RFLP in intron III of the factor IX gene for each ethnic group, including previously reported values for Chinese ${ }^{13}$ and Japanese. ${ }^{12}$ The RFLP frequencies for New Zealand resident Caucasians are similar to those of Caucasian populations in previous reports. ${ }^{2} 722$ In contrast, the $X m n I$ site and the TaqI site were virtually absent in the Pacific Island Polynesians. The frequencies of both sites in New Zealand Maoris was intermediate between Caucasian and Pacific Island Polynesian values.

\section{Discussion}

The results of New Zealand Caucasian controls for all six RFLP systems used were consistent with previously reported Caucasian communities. ${ }^{2} 5-7111920$ The relatively high (83\%) frequency of the $B c I$ site in the New Zealand Caucasians was unexpected, but could be the result of the small number of chromosomes analysed (47 X chromosomes). It is worth noting that the $95 \%$ confidence interval for this site overlaps with other reported frequencies. Important differences were observed between the Polynesians and Caucasians, and similarities between the Polynesian and Oriental populations. The factor VIII BglI polymorphism frequency in Caucasians is approximately 80 to $85 \%$, whereas in a total of $120 \mathrm{X}$ chromosomes in Polynesians only a single subject was found in whom the $B g l I$ site was absent. The nearly total lack of this polymorphism is also a characteristic of Chinese factor VIII genes. ${ }^{15}$ The intermediate frequency of the BglI site in 72 chromosomes from persons stating themselves to be Maori reflects the mixed racial composition of this New Zealand group. A New Zealand Maori was defined as $\geqslant 50 \%$ Maori heritage and allows up to $50 \%$ non-Polynesian (predominantly Caucasian) ancestry. The New Zealand Caucasian controls showed very little linkage disequilibrium between the $B c l I$ and $X b a I$ sites, consistent with other reports. ${ }^{520}$ In contrast there was almost complete linkage disequilibrium between these two sites in the Polynesians. The strong linkage disequilibrium shown in the Polynesian subjects is probably the result of a founder effect during the colonisation of the Pacific Islands. The short time period during which this occurred is insufficient for equilibrium to have developed between the $B c l I$ site and the $X b a I$ site. The linkage disequilibrium displayed by the Polynesians makes the combined use of both the $B c l I$ and $X b a I$ RFLPs of minimal benefit in improving informativeness. We found only a very small increase in informativeness when $X b a \mathrm{I}, B g I \mathrm{I}$, or both were added to the $B c l I$ study in this ethnic group.

The frequency distribution of the TaqI/St14.1 system $I$ in Maoris and Pacific Island Polynesians is more like the pattern observed in the Chinese ${ }^{15}$ than that found in persons of Caucasian origin. In system II, the $\beta$ allele was present in $41 \%$ of the Pacific Island Polynesians. The $\beta$ fragment is rare in Caucasians but is found in $43 \%$ of Chinese. ${ }^{15}$ Intragenic RFLPs were informative in 50 to $55 \%$ of Polynesian women, which increased to $78 \%$ when combined with the extragenic TaqI system. For Caucasians in this study, $60 \%$ were informative when all three intragenic sites were used, and this was increased to $77 \%$ when coupled with the extragenic TaqI system. Thus, when using DNA 
marker analysis, there will still be approximately 20 to $25 \%$ of women who will be uninformative and for these women accurate phenotypic data will remain essential. We propose a diagnostic strategy for haemophilia A affected families in Polynesian populations as follows. Technically the $B c I I$ results from both Southern blotting and PCR are easier to interpret. The $B c l$ I RFLP is therefore preferred in the initial assessment for haemophilia $\mathrm{A}$ carrier detection and prenatal diagnosis. Owing to linkage disequilibrium the $X b a I$ and $B g l I$ RFLPs will not increase the informativeness of the $B c l I$ results in most cases. The extragenic $T a q \mathrm{I} / \mathrm{St} 14.1$ system is very informative in Polynesian populations and could be used in uninformative $B c I I$ cases. However, caution must be exercised because of error owing to recombination when using extragenic systems.

Reports suggest that the factor IX TaqI and XmnI polymorphic sites are the most useful RFLPs for haemophilia B studies in Caucasians. ${ }^{2}$ The frequencies of these sites in New Zealand Caucasians support this observation. In contrast, we found only one chromosome with the polymorphic TaqI site out of a total of 120 Pacific Island Polynesian chromosomes and no polymorphic $X m n I$ sites out of a total of 116 Pacific Island Polynesian chromosomes. The allelic frequencies for these sites in the Maori group was intermediate between the full Polynesians and Caucasian frequencies, presumably reflecting mixed Polynesian and Caucasian ancestry. The TaqI and $X m n I$ sites also appear to be absent or of very low frequency in East Asians, ${ }^{12}{ }^{13}$ who in this respect resemble the Polynesians. For haemophilia B affected families the $T a q I$ and $X m n I$ RFLPs commonly used in Caucasian studies are of minimal value in Polynesian populations. As with the Japanese ${ }^{12}$ and Chinese, ${ }^{13}$ alternative intragenic RFLPs will have to be identified before a suitable diagnostic strategy of DNA analysis can be determined for Polynesian families. Alternatively, direct determination of the factor IX mutation using PCR coupled to a variety of methods, such as direct sequencing and mismatch analysis of heteroduplexes either on denaturing gradient gel electrophoresis or by chemical cleavage, should provide a diagnosis in most cases. ${ }^{23-28}$ These new strategies for the rapid detection of mutations may become the methods of choice in ethnic groups for which RFLP analysis is inadequate.

The Polynesian race is a distinct ethnic group which consists of approximately one million persons widely dispersed throughout the Islands of the central and south Pacific Ocean. More than one third of all Polynesians currently reside in New Zealand, including 300000 indigenous New Zealand Maoris and about 60000 recent immigrants from other South Pacific Island populations. The Polynesian race, a relatively new ethnic group, is thought to have been derived from the Lapita culture more than 3500 years ago. ${ }^{29}$ The colonisation of the Pacific Islands by the Polynesians is considered to have been a stepwise progression from the Melanesian Islands north of New Guinea eastwards through Fiji, Samoa, and Tonga to islands as remote as Hawaii, Easter Island, and New Zealand over a period of approximately 2500 years. The new RFLP data presented here from two separate loci on the $\mathrm{X}$ chromosome in Polynesians show similarities with the reported studies on populations of east Asian origin. The linkage disequilibrium between the $B c I I$ and $X b a I$ sites in the factor VIII gene is consistent with a theory of the Polynesian race originating from a small founder population less than 8500 year ago. This figure, derived from the equation $a=b[1-\varnothing] n^{*}$, is based on a recombination frequency equal to 0.00018 and assumes that the small founder population had complete linkage disequilibrium. Our genomic data support current concepts ${ }^{29} 30$ of a rapid and recent Polynesian colonisation of the Pacific Islands east of the Bismarcks by Lapita people, who were in turn derived from an east Asian population.

The authors wish to thank Dr K Fay, Auckland Hospital, for help in the collection of blood samples. This work was supported by grants from the New Zealand Haemophilia Society and the New Zealand Lottery Board.

${ }^{*} a=$ final frequency, $b=$ initial frequency, $\varnothing=$ recombination frequency, $n=$ time in generations. ${ }^{31}$

1 Ockelford PA, Benny AG, Van de Water NS, Berry EW. Haemophilia management in New Zealand: an Auckland perspective. NZ Med f 1989;102:189-91.

2 Winship PR, Anson DS, Rizza CR, Brownlee GG. Carrier detection in haemophilia B using two further intragenic fragment length polymorphisms. Nucleic Acids Res 1984;12: $8861-72$.

3 Kogan SC, Doherty M, Gitschier J. An improved method for prenatal diagnosis of genetic diseases by analysis of amplified DNA sequences. $N$ Engl f Med 1987;317:985-90.

4 Janco RL, Phillips JA, Orlando PJ, Woodard MJ, Wion KL, Lawn RM. Detection of hemophilia A carriers using intragenic factor VIII:C DNA polymorphisms. Blood 1987;69: $1539-41$.

5 Moodie P, Liddell MB, Peake IR, Bloom AL. Carrier detection in 50 haemophilia $A$ kindreds by means of three intragenic and two extragenic restriction fragment length polymorphisms. $\mathrm{Br} \mathcal{F}$ Haematol 1988;70:77-84.

6 Pecorara M, Casarino L, Mori PG, et al. Hemophilia A: carrier detection and prenatal diagnosis by DNA analysis. Blood 1987;70:531-5.

7 Camerino G, Grzeschik KH, Jaye M, et al. Regional localization on the human $X$ chromosome and polymorphism of the coagulation factor IX gene (hemophilia B locus). Proc Natl Acad Sci USA 1984;81:498-502.

8 Giannelli F, Anson DS, Choo $\mathrm{KH}$, et al. Characterisation and use of an intragenic polymorphism for detection of carriers of haemophilia B (factor IX deficiency). Lancet 1984;i:239-41.

9 Camerino GG, Oberle I, Drayna D, Mandel JL. A new Msp I restriction fragment length polymorphism in the haemophilia $B$ locus. Hum Genet 1985;71:79-81.

10 Hay CW, Robertson KA, Yong SL, Thompson AR, Growe GH, MacGillivray RTA. Use of a Bam HI polymorphism in the factor IX gene for the determination of hemophilia $B$ carrier status. Blood 1986;67:1508-11.

11 Antonarakis SE, Waber PG, Kittur SD, et al. Hemophilia A. Detection of molecular defects and of carriers by DNA analysis. N Engl F Med 1985;313:842-8. 
12 Kojima T, Tanimoto $M$, Kamiya $T$, et al. Possible absence of common polymorphisms in coagulation factor IX gene in Japanese subjects. Blood 1987;69:349-52.

13 Lubahn DB, Lord ST, Bosco J, et al. Population genetics of coagulation factor IX: frequencies of two DNA polymorphisms in five ethnic groups. Am $\mathcal{F}$ Hum Genet 1987;40:537-47.

14 Mikami S, Nishino M, Nishimura T, Fukui H. RFLPs of factor IX gene in Japanese haemophilia $B$ families and gene deletion in two high-responder-inhibitor patients. $\mathcal{F} p n \mathcal{F}$ Hum Genet 1987; 32:21-31.

15 Chan V, Chan TK, Liu VWS, Wong ACK. Restriction fragment length polymorphisms associated with the factor VIII-C gene in Chinese. Hum Genet 1988;79:128-31.

16 Kunkel LM, Smith KD, Boyer SH, et al. Analysis of human Ychromosome specific restricted DNA in chromosome variants. Proc Natl Acad Sci USA 1977;74:1245-9.

17 Southern EM. Detection of specific sequences among DNA fragments separated by gel electrophoresis. F Mol Biol 1975;98: $503-17$.

18 Feinberg AP, Vogelstein B. A technique for radiolabelling DNA restriction endonuclease fragments to high activity. Anal Biochem 1983;132:6-13.

19 Gitschier J, Drayna D, Tuddenham EGD, White RL, Lawn RM. Genetic mapping and diagnosis of haemophilia $A$ achieved through a Bcl-I polymorphism in the factor VIII gene. Nature 1985;314:738-40.

20 Wion KL, Tuddenham EGD, Lawn RM. A new polymorphism in the factor VIII gene for prenatal diagnosis of hemophilia A. Nucleic Acids Res 1986;14:4535-42.

21 Oberle I, Camerino G, Heilig R, et al. Genetic screening for hemophilia A (classic hemophilia) with a polymorphic DNA probe. $N$ Engl f Med 1985;312:682-6.
22 Hassan $\mathrm{HJ}$, Orlando M, Leonardi A, et al. Intragenic factor IX restriction site polymorphism in hemophilia B variants. Blood 1985;65:441-3.

23 Attree $O$, Vidaud $M$, Vidaud D, Lavergne JM, Goossens $M$. New strategies for the rapid detection and characterization of mutations in hemophilia B. Thromb Haemostas 1989;62:8.

24 Cariello NF, Scott JK, Kat AG, Thilly WG, Keohavong P. Resolution of a missense mutant in human genomic DNA by denaturing gradient gel electrophoresis and direct sequencing using in vitro DNA amplification. Am f Hum Genet 1988;42: 726-34.

25 Green PM, Bentley DR, Mibashan RS, Nilsson IM, Giannelli F. Molecular pathology of haemophilia B. EMBO $\mathcal{f} 1989 ; 8$ : 1067-72.

26 Koeberl DD, Bottema CDK, Buerstedde JM, Sommer SS Functionally important regions of the factor IX gene have a low rate of polymorphism and a high rate of mutation in the dinucleotide CpG. Am f Hum Genet 1989;45:448-57.

27 Bottema CDK, Koeberl DD, Sommer SS. Direct carrier testing in 14 families with haemophilia B. Lancet 1989;ii:526-9.

28 Montandon AJ, Green PM, Giannelli F, Bently DR. Direct detection of point mutations by mismatch analysis: application to haemophilia B. Nucleic Acids Res 1989;17:3347-58.

29 Diamond JM. Express train to Polynesia. Nature 1988;336: 307-8.

30 Hertzberg M, Mickleson KNP, Serieantson SW, Prior JF, Trent RJ. An Asian-specific 9-bp deletion of mitochondrial DNA is frequently found in Polynesians. Am F Hum Genet 1989;44: $504-10$.

31 Graham JB, Green PP, McGraw RA, Davis LM. Application of molecular genetics to prenatal diagnosis and carrier detection in the hemophilias: some limitations. Blood 1985;66:759-64. 